\title{
The Sausapor Declaration: Challenges in promoting good governance to protect customary communities and natural resources in Tambrauw district, West Papua
}

\author{
Sepus M.Fatem ${ }^{1,2, *}$, Yaved Syufi ${ }^{3}$, Josefina Baru ${ }^{3}$, Jonni Marwa ${ }^{1}$, Yubelince Y. Runtuboi ${ }^{1}$, Viktor \\ Tawer $^{4}$, Saur Situmorang ${ }^{2}$, Ferawati R. Runtuboi ${ }^{5}$ \\ ${ }^{1}$ Faculty of Forestry, Universitas Papua, Jl. Gunung Salju Amban, Manokwari, Indonesia \\ ${ }^{2}$ Tambrauw regent office, Jl. Irawiam-Fef, Tambrauw, West Papua, Indonesia. \\ ${ }^{3}$ Faculty of Linguistic, Universitas Papua, Jl. Gunung Salju Amban, Manokwari, Indonesia \\ ${ }^{4}$ Tambrauw Enviromental office. Jl. Irawiam Fef, Tambrauw, Indonesia. \\ ${ }^{5}$ Faculty of Marine and Fisheries, Universitas Papua. Jl. Gunung Salju Amban, Manokwari, Indonesia \\ *Correspondence: Sepus M. Fatem, E-mail: sepus_fatem@yahoo.com
}

\begin{abstract}
The Sausapor Declaration has served as a stepping stone towards convening and balancing the dynamics of governmental politics, conservation efforts, the protection of customary communities' rights, and the sustainable management of natural resources in Tambrauw District. The Declaration supported the establishment of Tambrauw as a Conservation District, while also acknowledging the rights of customary communities in shaping political priorities of the local government, which include: a) stewardship of extensive remaining tropical forests ( $91.9 \%$ forest cover); b) management of protected areas, which represent $77-80 \%$ of the total area of the District; c) acknowledging the cultural traditions of five major indigenous groups; and, d) securing the active support of formal institutions for these goals. Two stages have shaped the effort to establish the Conservation District. The first stage involved the period prior to the formal declaration, while the second ecompasses development and implementation of related policies. Establishing local regulations and protecting local communities required extensive lobbying with the provincial and national government, as well as advocacy in various seminars, including both national and international conferences that provided strategic opportunities for securing support for the Conservation District. These steps have been instrumental in gaining legitimacy and public support for relevant conservation policies and for protecting the rights of customary communities. As one example, the review of Tambrauw spatial planning documents (RTRW) led to prioritizing eco-tourism as a leading sector for economic development, along with the creation of an overall agropolitan and renewable energy strategy.
\end{abstract}

Keywords: Conservation District; Tambrauw; customary community; sustainable development; West Papua

Tambrauw is the first district in Tanah Papua to declare itself a Conservation District, including a concerted policy for the protection of customary communities, as its core local development agenda. The overall agenda is reflected in formal and legally sanctioned local development planning documents. Two out of the six points in the local development mission statement are related to conservation and the protection of customary communities. The fifth point commits "to protect the environment by designating Tambrauw as a conservation district," and the sixth "to recognize and respect the basic rights of customary communities in Tambrauw District" (Fatem et al., 2018).

Tambrauw is the first district in Tanah Papua to declare itself a Conservation District, including a concerted policy for the protection of customary communities, as its core local development agenda. The overall agenda is reflected in formal and legally sanctioned local development planning documents. Two out of the six points in the local development mission statement are related to conservation and the protection of customary communities. The fifth point commits "to protect the 
environment by designating Tambrauw as a conservation district," and the sixth "to recognize and respect the basic rights of customary communities in Tambrauw District" (Fatem et al., 2018).

Located on the northern coast of West Papua Province, Tambrauw consists of a highly diverse ecological region with unique socio-cultural significance. Its forest cover comprises $91.9 \%$ of the province (Fatem, 2019b) and $77-80 \%$ of its total administrative region functions as part of the protected area system within the two provinces of Tanah Papua (Fatem \& Asem, 2015). Therefore, Tambrauw holds a strategic position in terms of having abundant forest resources and promoting adaptive measures to mitigate global climate change. In Tambrauw District, there are five major ethnic groups who still maintain their customary rights and sustainably protect these forest and natural resources. While they work to sustain the forest, the forest also sustains them. Tambrauw became a new autonomous district in 2008. However in 1982, long before its establishment as a new administrative region, a significant area of Tambrauw had been designated as part of a series of protected areas. On 10 November, 1982, the Minister of Agriculture, in Decree No. 820/UM/II/1982, designated the North Tambrauw Nature Reserve, an area covering 368,365 hectares, Jamursba Medi Wildlife Sanctuary (51.26 hectares), Pantai Wewe Kwoor Nature Reserve (100 hectares), Pantai Sausapor Nature Reserve (62.66 hectares), and the South Tambrauw Nature Reserve (519.62 hectares) (Petocz \& Raspado, 1987).

When Gabriel Asem took office as the head of the Tambrauw District for two periods (from 2011-2016 and 2017-2022), natural resource conservation and the protection of indigenous communities became a focus of the political agenda, and these issues were incorporated into the formal goals of local development planning. In an early interview, Asem revealed that when Tambrauw was established, the new district faced significant challenges related to spatial planning. Given the fact that $80 \%$ of its territory had been designated as protection areas, local officials were vulnerable to lawsuits when utilizing certain areas for development activities and public services without "permission." Therefore, during the period of 2011-2016, Asem emphasized an adaptive model in order to accommodate the dual concerns of conservation and economic development. The ultimate goal was to develop effective mutual interactions for good governance, forest resource protection, and the basic rights of customary communities (Fatem, 2019b)

The Tambrauw District mid-term development plan of 2011-2016 provided a roadmap for the establishment of the Conservation District. The plan included two main stages: the first stage covered the pre-conditions of formally establishing Tambrauw as a Conservation District, and the second stage focused on implementation (Bappeda Tambrauw, 2011; 2018). From a spatial planning perspective, the Tambrauw Spatial Planning documents (RTRW) set forth this vision, i.e., "to promote quality, open and efficient regional spatial management of the Tambrauw District, and to work toward a self-sufficient and prosperous district through the sustainable use of natural resources" (BAPPEDA Tambrauw, 2011).

The goals and policies in the development of the Conservation District were then translated by several local work units into their own vision and mission statements, and into tangible work programs. The Tambrauw Forestry Office in $\mathbf{2 0 1 2}$ drafted a master planning document on forest management, which included the following mission statement: "to promote the Conservation District in order to increase the productivity of forest zones for the purpose of achieving people's independence and economic prosperity by 2033" (Dinas Kehutanan Tambrauw, 2012).

The pre-condition stage (2012-2016) was marked by feasibility studies of the Conservation District, including consultations, active lobbying, and policy advocacy at the ministerial level (Ministry of Environment and Forestry, Home Affairs, National Development Planning, and the REDD+ Management Team). At the provincial level, the stage also involved the formation of partnerships between the Tambrauw District Government and several NGOs, and participation in a number of national and international conferences, such as the Governors' Climate Forest (GCF) Meeting in Barcelona in 2015, the United Nations Framework Convention on Climate Change (COP 21) in 2015, and the Oslo Tropical Forest Forum in 2018. These occasions offered a strategic 
opportunity for Tambrauw District to draw international attention and support for the idea of establishing the Conservation District. This pre-condition stage also included the formulation of a regulatory framework, including support for customary communities. These regulations provided the legal foundation for the Conservation District.

The Conservation District was formally declared on 29 October 2018, coinciding with the celebration of Tambrauw District's 10 Anniversary. The declaration was made by District Head Gabriel Asem, accompanied by Ir. Wiratno., M.Sc., Director General of Natural Resources and Ecosystems Management, representing the Indonesian Ministry of Environment and Forestry. The ceremony was attended by representatives of other key agencies and organizations, outlined in the list below:

Table 1. List of actors attending the declaration

\begin{tabular}{|c|c|}
\hline Actor & Task \\
\hline Ir. F. Runaweri, MM & $\begin{array}{l}\text { The West Papua Head of Forestry Office representing the governor of } \\
\text { West Papua }\end{array}$ \\
\hline $\begin{array}{l}\text { Letkol Infanteri D. } \\
\text { Panggabean }\end{array}$ & $\begin{array}{l}\text { Representing the Military Command Unit (Danramil) of Sorong and the } \\
\text { Regional Military Commander (Pangdam) XVIII Kasuari- West Papua } \\
\text { Barat) }\end{array}$ \\
\hline AKBP Dewa Made Sidan & The Chief of Sorong Police (Kapolres Sorong), representing the \\
\hline $\begin{array}{l}\text { Sutrahna, S.IK } \\
\text { Kosmas Baru, S.Hut }\end{array}$ & $\begin{array}{l}\text { Regional Police Chief (Kapolda of West Papua, } \\
\text { The head of Tambrauw People's Representative Council }\end{array}$ \\
\hline Meki Yekwan & Representing customary communities from Abun \\
\hline YohanesSundo & Representing church leaders \\
\hline Hadi Fernandus & Representing WWF Sausapor \\
\hline Yunus Yumte & Representing Samdhana Institute \\
\hline Malik & Representing Yayasan Epistema \\
\hline Abdon Nababan & $\begin{array}{l}\text { Representing Aliansi Masyarakat Adat Nusantara (Alliance of } \\
\text { Indigenous Communities in Indonesia) }\end{array}$ \\
\hline Fourly & Representing Yayasan Paradisea \\
\hline Deki Yesnat & Representing Yayasan Marwasnat \\
\hline Aris & Representing Yayasan URDI \\
\hline
\end{tabular}

The Tambrauw Declaration consisted of five main points (see Box 1 below). From a political perspective, the Declaration was closely related to the broader idea of designating West Papua as a Conservation Province (Cámara-Leret et al., 2019). The commitments spelled out in the Declaration describe Tambrauw District's vision of promoting conservation policies and protecting the rights of customary communities. As a district with abundant forest resources, Tambrauw's conservation policies must be aligned with those articulated at the provincial level. These common goals allow the Province and the District to work together to realize these proposed conservation policies.

As part of the process to achieve these policies, the government of Tambrauw District issued Regional Regulation No. 5/2018 (re the Conservation District) and Regional Regulation No. 6/2018 (re the Recognition and Protection of Customary Communities in Tambrauw District). The regulations, approved at the same time, underscored the importance of the interrelation of conservation initiatives and respect for traditional communities, and that sustainable use of natural resources can only be achieved through efforts to minimize conflicts between economic development and the goals of conservation. 


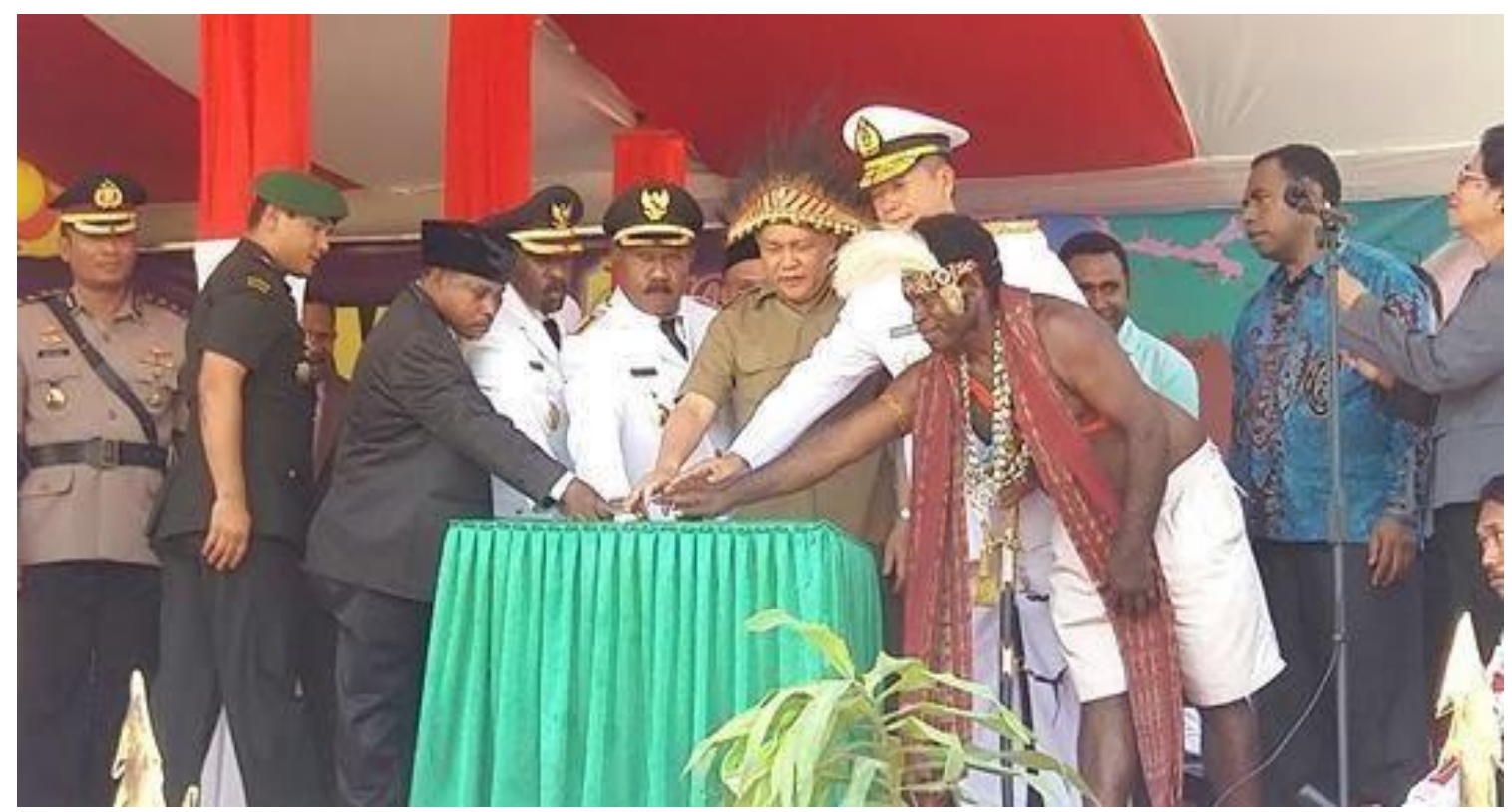

Figure 1. Declaration of Tambrauw Conservation district

These legal products were prepared over a period of three years (2015-2018) and received the full support of various development partners, including the Samdhana Institute, World Wildlife Fund Papua, Epistema Institute, Marwasnath and Aka Wuon (local community-based NGOs), as well as the Faculty of Forestry at Universitas Papua (UNIPA) (Fatem et al., 2018). The involvement of these development partners was accomplished through the work of a collaborative network involving the Tambrauw District government and a variety of stakeholders, including customary organizations, NGOs, and universities. This collaborative effort provided oversight for the preparation of policies and action plans, and continues to support implementation of conservation policies, through consultation with potential affected communities at the ground level. NGO support for the creation of the Conservation District is consistent with Krott et al. (2014) and Maryudi (2011), who concluded that the participation of development partners is critical to effective engagement of various actors on conservation issues.

Following the establishment of Tambrauw as a Conservation District in 2018, the next step involved determining strategic local implementation actions. The overall development strategy of Tambrauw District emphasizes the optimization of local resource potential - the effective use of natural resources based on the cultural capital of customary communities.

Ecotourism also provides a distinct opportunity for the various commitments described in the declaration of the Conservation District, and it has become the lead priority for local economic development. Ecotourism is based on principles of sound environmental management, and it is deeply concerned with sustainable development (Wang and Min, 2009). The natural biophysical potential of the region is immense, with rich flora and fauna, established protected forest and marine conservation areas, and the unique cultural traditions of customary communities, which collectively provide a strong foundation for ecotourism development. The pristine condition of nature and culture must be safeguarded while being optimized to deliver additional values and economic benefits to the people of Tambrauw.

The Tambrauw Tourism Office created a Master Plan for Tourism Development (Dinas Pariwisata Tambrauw, 2017). The Master Plan recommends two main areas for ecotourism development in Tambrauw, Blue Wonder and Green Wonder. Blue Wonder refers to tourist destinations along coastal areas, while Green Wonders are terrestrial destinations. The Tambrauw 
District has now listed 63 tourism destinations, seven so-called "magnificent attractions", and five "differentiators" (five unique tourist attractions that differentiate Tambrauw tourism potential from other regions), based on various criteria. These categorizations were determined based on a joint study between The Centre of Regional Development Studies, University of Gajah Mada and the Tambrauw Ecotourism Office (Rencana Induk Pembangunan Pariwisata Kabupaten Tambrauw, 2017). The Local Development Planning Agency (Bappeda) of Tambrauw subsequently translated Conservation District policies into revisions to the Tambrauw District Spatial Plan (RTRW). The revised spatial planning documents are instrumental to eco-tourism development, as they promote infrastructure development (especially roads) to provide access to destination sites (e.g., for birdwatching). In some locations, however, the plan promotes road construction through forest protected areas to ensure effective distribution of goods and services. Another important aspect involves public education, to ensure active participation in eco-tourism management, since these changes likely have consequences for the government and for local communities, for example in providing for skills development for new job opportunities.

Successful eco-tourism requires three major elements: amenities, accessibility, and attractions (Buckley, 1996). As the core strategy for Tambrauw's Conservation District, ecotourism, in principle, poses minimal risk to environmental degradation, yet provides employment opportunities that substantially contribute to conservation and economic development. The RTRW is not limited to eco-tourism development, but also includes an emphasis on the development of the agropolitan zone, guided by the District Agriculture and Livestock Office. This involves the development of four economic growth centers, supports the development and utilization of renewable energy for electricity, and focuses on social forestry initiatives.

Implementing the Sausapor Declaration presents challenges between the commitments outlined in the Declaration and the fact that development needs include clearing forest areas for roads, building new settlements, but also maintaining the continuity of existing land use (e.g., established settlements within designated protected areas). For the Tambrauw government, the immediate response to the Sausapor Declaration is to ensure that the revisions to the RTRW district accommodate commitments in the declaration.

In addition to compliance with the law requiring that the RTRW be revised every five years, the Declaration recommended that the RTRW undergo significant adjustments. Since 2013, the administrative area within the Tambrauw District expanded, as the number of villages and subdistricts increased. This growth also results in the corresponding need to build more access to infrastructure. As of 2020, Tambrauw District is divided into 29 sub-districts, consisting of 216 villages, which were designated based on Law No. 14/2013 on Changes in Coverage Area and Addition of Sub-districts. The proposal to decrease the coverage of protection forests from $76 \%$ to $67 \%$, which was made by the local government and customary communities runs counter to Article 1 of the Sausapor Declaration, and has posed its own challenges to the District's development agenda.

The revised RTRW provides for various development interventions and provision of public services. Infrastructure development, in the form of roads and bridges, improving the economy and education, and producing renewable energy are all considered priorities. In terms of human resources, Tambrauw has one of the lowest Human Development Indexes (51.95) in West Papua Province (Badan Pusat Statistik Provinsi Papua Barat, 2018).

This is a bitter irony for Tambrauw, and for the people of Tanah Papua, given the stark contrast between the region's poverty and the abundance of natural resources. The establishment of the Conservation District does not mean limiting people's access to natural and wild resources. If this were the case, the Conservation District would only exacerbate pockets of poverty in Tambrauw. The vision for the Conservation District provides widespread opportunities to improve the quality of life for the people of Tambrauw. 
Despite its status as a Conservation District, a recent study revealed that several companies have already received government concessions: six in the forest sector, and three in the mining sector (Fatem, 2019b). Therefore, the local government must open negotiations with affected stakeholders. Negotiations over these concession areas are a necessity, given existing discrepancies and potential conflicts with plans outlined in the Declaration. As one example, despite the fact that the Ministry of Environment and Forestry designated a forest area as a conservation zone, the Ministry of Energy and Mineral Resources also granted an overlapping permit (Ijin Usaha Pertambangan, or a Mining Business License) for exploitation of the same area. This points to the clear need to seek alternatives through a careful review of these concession areas. There are also indications that illegal operations are already taking place; some companies are reported to have taken advantage of customary communities' conditions to obtain concession licenses.

Tambrauw's fragile economic conditions and limited education means that local people can be easily manipulated through any terms that allow them to meet their daily needs. As a case in point, they may not consider the long-term consequences of mining operations in their area, relative to short term gains that address more immediate needs. The mining concessions were granted since 2006, before the Tambrauw District itself was established. Since then, some parties have initiated operations within forest protected areas, yet no single party has received a formal concession from the Ministry of Environment and Forestry. In 2016-2017, an illegal gold mining operation had been established in Sungai Kasi, in Kampong Pubuan, Kebar sub-district, in eastern Tambrauw. This case drew widespread public attention because five foreign workers were caught by a joint team of Indonesian police and armed forces. This was of special interest because the workers had proper immigration and working documents.

Box 1: Sausapor Declaration

1. Maintaining the functions of the conservation and protection forest zones, including the coverage of protection forests and marine protection zones, as having been designated by regulations enforced by the West Papua Province and those by the central government.

2. Ensuring and giving legal recognition on the rights of customary communities in Tambrauw District;

3. Developing a regional spatial plan to ascertain that the implementation of local developments, public services, and conservation efforts, and the protection of the customary communities' culture and assets are all integrated into the development planning of the conservation district and are conducted by and for customary communities;

4. Developing and strengthening regulations, good governance, infrastructure, and funding to support local development, the protection and utilization of biodiversity potential in Tambrauw District;

5. Working in partnership with customary communities, business practitioners, and other parties for the purpose of developing business units that support the local potential across Tambrauw District.

Despite the fact that conservation has become the main goal of the Tambrauw roadmap for development, many challenges remain in achieving the long-term goals for the Conservation District. These challenges: strong commitment and leadership, robust institutions, enhanced human resource capacity, community economic empowerment, law enforcement, education and protection of customary communities, application of science and technology, and effective management of natural resources on the ground (e.g., developing social forestry within the context of customary forests) are all in line with President Jokowi's national development strategy, Nawacita (Fatem, 2019a; Fisher, Dhiaulhaq, \& Sahide, 2019). Nawacita outlines the nine development principles established by the president, reflecting the priorities of the present administration. The vision of Nawacita is to make Indonesia politically sovereign, economically independent, and with its own unique development personality, rooted in its local culture. One of the core commitments of Nawacita is to encourage development of the so-called "periphery zones" of more remote areas 
in the archipelago. Tambrauw District must continue to promote leadership development and capacity building, more consistent spatial planning processes, public education on the value of conservation, and the support of customary communities. To be successful, the District must also deliver on commitments to the economic empowerment of local businesses. Gabriel Asem, elected yet again to lead Tambrauw District for the period of 2017-2022, appears dedicated to continue to work toward addressing these challenges.

\section{Acknowledgements}

The authors are grateful to Tambrauw development partnerships, namely WWF Sausapor (Hadi Fernandus and team), Akawuon (Soter Hae and team), Marwasnath Foundation (Deki Yesnath and team), Paradisea Foundation (Fourly and team), Samdhana Institute (Yunus Yumte and team) and Epistema Foundation (Yance Arizona, Malik and team) for their support in the form of funds, assistance, technology transfer, lobbying, and advocacy to help Tambrauw be declared a conservation district.

\section{Conflicts of Interest}

The authors declare no conflict of interest.

\section{References}

BAPPEDA Tambrauw. (2011). Rencana Tata Ruang Wilayah Kabupaten Tambrauw. Sausapor.

BAPPEDA Tambrauw (2018). Rencana Tata Ruang Wilayah Kabupaten Tambrauw Perubahan 20182038.

Buckley, R. (1996). Sustainable tourism: Technical issues and information needs. Annals of Tourism Research, 23(4), 925-928.

Cámara-Leret, R., Schuiteman, A., Utteridge, T., Bramley, G., Deverell, R., Fisher, L. A., ... Heatubun, C. (2019). The Manokwari declaration: Challenges ahead in conserving 70\% of Tanah Papua's forests. Forest and Society, 3(1), 148-151. doi: https://doi.org/10.24259/fs.v3i1.6067

Dinas Kehutanan Tambrauw (2012). Master Plan Pembangunan Kehutanan Kabupaten Tambrauw. Sausapor.

Dinas Pariwisata dan Kebudayaan Kabupaten Tambrauw. (2017). Rencana Induk Pembangunan Pariwisata Tambrauw.

Fatem, S. M. (2019a). Connecting social forestry to conservation policies in Tanah Papua. Forest and Society, 3(1), 141-147.doi: https://doi.org/10.24259/fs.v3i1.5865

Fatem, S. M. (2019b). Konstruksi Kabupaten Konservasi Tambrauw di Provinsi Papua Barat; Kontestasi Aktor, Peran Power, Biofisik dan Adaptasi. Universitas Gadjah Mada.

Fatem, S. M., Awang, S. A., Pudyatmoko, S., Sahide, M. A. K., Pratama, A. A., \& Maryudi, A. (2018). Camouflaging economic development agendas with forest conservation narratives: A strategy of lower governments for gaining authority in the re-centralising Indonesia. Land Use Policy, 78, 699-710. doi: https://doi.org/10.1016/J.LANDUSEPOL.2018.07.018

Fisher, M. R., Dhiaulhaq, A., \& Sahide, M. A. K. (2019). The politics, economies, and ecologies of indonesia's third generation of social forestry: An introduction to the special section. Forest and Society, 3(1), 152-170. doi: https://doi.org/10.24259/fs.v3i1.6348

Fatem, S. M., \& Asem, G. (2015). Kabupaten konservasi sebagai political action pemerintah daerah dalam mendukung konservasi sumberdaya alam hayati: Studi kasus Kabupaten Tambrauw, Papua Barat. Pros Sem Nas Masy Biodiv Indon, 1(September), 1403-1410. doi: https://doi.org/10.13057/psnmbi/m010624

Krott, M., Bader, A., Schusser, C., Devkota, R., Maryudi, A., Giessen, L., \& Aurenhammer, H. (2014). Actor-centred power: The driving force in decentralised community based forest governance. Forest Policy and Economics, 49, 34-42. doi: https://doi.org/10.1016/j.forpol.2013.04.012 
Maryudi, A. (2011). The Contesting Aspirations in the Forests: Actors, Interests and Power in Community Forestry in Java, Indonesia. Universitätsverlag Göttingen.

Petocz, R. G., \& Raspado, G. P. (1987). Konservasi Alam Dan Pembangunan Di Irian Jaya: Strategi Pemanfaatan Sumber Daya Alam Secara Rasional. Grafiti Pers.

Wang, H., \& Min, T. (2009). Research on community participation in environmental management of ecotourism. International Journal of Business. Retrieved from http://citeseerx.ist.psu.edu/viewdoc/download?doi=10.1.1.859.3780\&rep=rep1\&type=pdf 